\title{
Loss of soil organic carbon in Swiss long-term agricultural experiments over a wide range of management practices
}

\author{
Sonja G. Keel ${ }^{\mathrm{a}, *}$, Thomas Anken ${ }^{\mathrm{b}}$, Lucie Büchi ${ }^{\mathrm{c}, 1}$, Andreas Chervet ${ }^{\mathrm{d}}$, Andreas Fliessbach ${ }^{\mathrm{e}}$, \\ René Flisch ${ }^{\mathrm{f}}$, Olivier Huguenin-Elie ${ }^{g}$, Paul Mäder ${ }^{\mathrm{e}}$, Jochen Mayer ${ }^{\mathrm{f}}$, Sokrat Sinaj ${ }^{\mathrm{c}}$, \\ Wolfgang Sturny ${ }^{\mathrm{d}}$, Chloé Wüst-Galley ${ }^{\mathrm{a}}$, Urs Zihlmann ${ }^{\mathrm{h}}$, Jens Leifeld ${ }^{\mathrm{a}}$ \\ ${ }^{\text {a } C l i m a t e}$ and Agriculture, Agroecology and Environment, Agroscope, Zurich, Switzerland \\ ${ }^{\mathrm{b}}$ Digital Production, Competitiveness and System Evaluation, Agroscope, Tänikon, Switzerland \\ ${ }^{\mathrm{c}}$ Field crop systems and Plant nutrition, Plant Production Systems, Agroscope, Nyon, Switzerland \\ ${ }^{\mathrm{d}}$ Bern Office of Agriculture \& Nature, Soil Conservation Service, Zollikofen, Switzerland \\ ${ }^{\mathrm{e}}$ Research Institute of Organic Agriculture, Frick, Switzerland \\ ${ }^{\mathrm{f}}$ Water Protection and Substance Flows, Agroecology and Environment, Agroscope, Zurich, Switzerland \\ ${ }^{\mathrm{g}}$ Forage Production and Grassland Systems, Animal Production Systems and Animal Health, Agroscope, Zurich, Switzerland \\ ${ }^{\mathrm{h}}$ Soil Fertility and Soil Protection, Agroecology and Environment, Agroscope, Zurich, Switzerland
}

\section{A R T I C L E I N F O}

\section{Keywords:}

Soil carbon sequestration

Organic amendments

Crop rotation

Cover crops

Permanent grassland

Fertilization, 4p1000

\begin{abstract}
A B S T R A C T
Soil carbon sequestration (SCS) is one of the cheapest and technically least demanding carbon dioxide $\left(\mathrm{CO}_{2}\right)$ removal (CDR) or negative $\mathrm{CO}_{2}$ emission technologies. For a realistic assessment of SCS, it is critical to evaluate how much carbon (C) can be stored in soil organic matter under actual agricultural practices. This includes typical crop rotations and fertilization strategies, depends on resources that are available (e.g. farmyard manure (FYM)) and are affordable for farmers. Furthermore, it is important to assess SCS based on given climatic and soil conditions. Here, we evaluate changes in soil C storage for Switzerland using data from eleven long-term field experiments on cropland and permanent grassland that include common local practices.

At all sites, changes in soil organic carbon (SOC) stocks were measured in topsoil $(\sim 0-0.2 \mathrm{~m})$ in response to a total of 80 different treatments including different types of mineral or organic fertilization (e.g. FYM, slurry, peat, compost) or soil management (tillage vs. no-till). The treatments were applied to different, diverse crop rotations or grass mixtures that are representative for Switzerland. We found that topsoils lost $\mathrm{C}$ at an average rate of $0.29 \mathrm{MgC} \mathrm{ha}{ }^{-1} \mathrm{yr}^{-1}$, although many of the investigated treatments were expected to lead to SOC increases. Based on a linear mixed effects model we showed that SOC change rates $(\Delta S O C)$ were driven by $C$ inputs to soil (harvest residues and organic fertilizer), soil cover and initial SOC stocks. The type of land use or soil tillage had no significant effect. Our analysis suggests that current efforts to manage soils sustainably need to be intensified and complemented with further techniques if Switzerland wants to achieve the goal of the 4 per 1000 initiative.
\end{abstract}

\section{Introduction}

Globally air temperatures have already increased by about $1{ }^{\circ} \mathrm{C}$ relative to pre-industrial levels (IPCC, 2018). To limit this human-induced warming to 1.5 degrees, we need to depend, in part, on CDR or negative
$\mathrm{CO}_{2}$ emission technologies. These can neutralize emissions for which no mitigation measures have been identified or can be used to achieve netnegative emissions following an overshoot of the 1.5-degree pathways. Several CDRs exist, all having their advantages and disadvantages (Minx et al., 2017; Fuss et al., 2018). They can be characterized as

\footnotetext{
* Corresponding author.

E-mail addresses: sonja.keel@agroscope.admin.ch (S.G. Keel), thomas.anken@agroscope.admin.ch (T. Anken), L.A.Buchi@greenwich.ac.uk (L. Büchi), andreas.chervet@vol.be.ch (A. Chervet), andreas.fliessbach@fibl.org (A. Fliessbach), rene.flisch@agroscope.admin.ch (R. Flisch), olivier.huguenin@agroscope.admin.ch (O. Huguenin-Elie), paul.maeder@fibl.org (P. Mäder), jochen.mayer@agroscope.admin.ch (J. Mayer), sokrat.sinaj@agroscope.admin.ch (S. Sinaj), wolfgang.sturny@vol.be.ch (W. Sturny), chloe.wuest@agroscope.admin.ch (C. Wüst-Galley), urs.zihlmann@agroscope.admin.ch (U. Zihlmann), jens.leifeld@agroscope.admin.ch (J. Leifeld).

${ }^{1}$ Present address: Natural Resources Institute, University of Greenwich, Chatham, England.
} 
biological or technological options (Smith and Friedmann, 2017). While the biological approaches such as biomass energy carbon capture and storage (BECCS) and afforestation have the advantage of being cheaper and closer to deployment compared to engineered methods such as direct air capture or enhanced weathering, they have the disadvantage of being more vulnerable to reversal (UNEP, 2017).

Soil C sequestration (SCS) belongs to the biological options. It is defined as a change in land management that leads to an increase in the soil $\mathrm{C}$ content and therefore a net uptake of $\mathrm{CO}_{2}$ from the atmosphere. Due to its large potential, the international " 4 per 1000 " initiative was launched at the COP21 (2015 Paris Climate Conference) to foster agricultural practices that enhance soil C (https://www.4p1000.org/). Minasny et al. (2017) estimated that in the top $1 \mathrm{~m}$ of agricultural soils, between 2-3 Pg C year ${ }^{-1}$ could be sequestered, thereby offsetting about one third of the global anthropogenic greenhouse gas (GHG) emissions. In contrast to afforestation or BECCS, SCS has the advantage that it does not compete with food production. Increasing the soil $\mathrm{C}$ content of mineral soils also has many co-benefits, such as improved soil quality, enhanced resilience to climatic extremes or even higher productivity if SOC is low (Pan et al., 2009). However, SCS also has a few disadvantages. The most important is that it is reversible if practices are not maintained, because soil $\mathrm{C}$ is continuously decomposed. Additionally, soil C sequestration is finite, as soils become $\mathrm{C}$ saturated and SOC stocks tend to equilibrate (Johnston et al., 2009). Furthermore, there are practices that increase emissions of other GHGs (e.g. fertilization of deficient soils with $\mathrm{N}$ leads to $\mathrm{N}_{2} \mathrm{O}$ emissions), potentially resulting in no effect on the GHG balance or even enhanced GHG emissions.

The amount of organic $\mathrm{C}$ in soil is dependent on several factors, but, at a given site, the balance of $\mathrm{C}$ inputs (e.g. roots, manure, and residues) and losses (mainly through respiration) is the crucial driver (Buyanovsky and Wagner, 1998). Soil C sequestration can thus be achieved by increasing $\mathrm{C}$ inputs or by reducing losses. Many different practices to improve SCS exist (Smith et al., 2008; Lal, 2011), but not all are suitable for each region or country. Potential strategies depend on many local factors such as agricultural practices including crop rotations and fertilization regimes, soil type, or climatic conditions.

Here, we assess SCS in agricultural topsoils of Switzerland under current incentives for sustainable soil management and under experimental settings. As a result of stringent conditions for subsidies that were implemented in 1998, local practices differ (or have differed) from practices in many European countries (Common Agricultural Policy towards 2020) or temperate regions in general. For farms with more than three ha cropland, for example at least four different crops need to be planted in rotation on arable land, and soils need to be covered by winter or cover crops when the main crop is harvested before end of August to receive subsidies based on 'Proof of Ecological Performance' regulations. Grass-clover ley is often part of the crop rotation. Cereal straw is usually removed and used for animal bedding, but returned to the field together with manure (i.e. FYM). It is therefore critical to evaluate Swiss SCS under these conditions. Based on a study from Bavaria, a region very similar to Switzerland in terms of climate and pedogenesis, cropland and grassland soils theoretically have the potential to sequester four times the amount of $\mathrm{CO}_{2}$-equivalents in the long-term as released by total GHG emissions annually (Wiesmeier et al., 2014).

To evaluate possible SCS strategies for Switzerland, we analyze for the first time results from eleven long-term field experiments (Table 1). At all sites, SOC stock changes in the upper $0.2 \mathrm{~m}$ (or less if equivalent soil masses could be calculated) of soil were measured in response to 80 treatments (2-24 per site) applied over 10 to 60 years. They included combinations of mineral and organic fertilizations (Table S1, Supplement), different types of crop rotations (e.g. including or excluding grass-clover ley), entire management systems (organic versus conventional) or different cutting frequencies for permanent grassland. Agricultural practices that are typical for Switzerland were evaluated, as well as extreme treatments ranging from no nutrient additions to four times the theoretical crop nutrient uptake (Richner and Sinaj, 2017). We thus address following questions: are Swiss agricultural topsoils under common and experimental practices $\mathrm{C}$ sinks or sources? Which factors drive SOC change rates?

\section{Material and methods}

\subsection{Description of experiments}

Most of the experiments have been described in detail elsewhere. We therefore only characterize them briefly (Tables 1,2, S1; Fig. 1). Information regarding site histories is given in Table S2.

The Zurich Organic Fertilizer Experiment (ZOFE) compares twelve different fertilization treatments (organic and mineral fertilizers (nitrogen $(\mathrm{N})$, phosphorus $(\mathrm{P})$ and potassium $(\mathrm{K})$ ) and their combination) applied to a 8-year crop rotation including grass-clover ley (main species: Poa pratensis L., Lolium perenne L., Festuca pratensis Huds., Dactylis glomerata L., Trifolium repens L., Trifolium pratense L.), winter wheat (Triticum aestivum L.), grain maize (Zea mays L.), and potato (Solanum tuberosum L.) (Oberholzer et al., 2014). Prior to the experiment, the field was a natural grassland under low intensity management (Walther et al., 2001). The experiment Demo87 (Demo) was set up to assess different nutrient deficiencies and compare mineral versus organic fertilization. The 7-year crop rotation includes rapeseed (Brassica napus L.), sugar beet (Beta vulgaris L.), potato, ley, maize. Experiment p24A tests a large number of different combinations of organic and mineral fertilizers that are applied at different rates to a 6-year crop rotation with winter wheat, grain maize, rapeseed and summer barley (Hordeum vulgare L.) (Maltas et al., 2018). In close vicinity, p29C was set up to study different soil management practices such as minimum tillage (Büchi et al., 2017). The 4-year crop rotation is composed of winter wheat, winter rapeseed and grain maize. The plots are fertilized with mineral fertilizer according to Swiss guidelines (Richner and Sinaj, 2017). From 1969-2006 wheat straw was exported, while maize and rapeseed residues were chopped and left on the field. In the year 2000, cover crops were sown before grain maize. Because soil texture and SOC stocks vary strongly at this site, the experimental field is divided into two parts. The DOK experiment (D: biodynamic, O: bioorganic, K: conventional) compares management systems that differ mainly regarding type and intensity of fertilization and methods of plant protection (Mäder et al., 2002; Fließbach et al., 2007). The treatments were applied to plots with identical crop rotations (that were repeated three times, but started in different years (subplots A, B, C)). Of the regular intensity treatments, we consider subplots $\mathrm{A}$ only. The 7-year crop rotation included potatoes, winter wheat, beetroots, winter barley and two subsequent years of ley. The experiment Oberacker (Ober) was established to compare conventional ploughing with notill (Chervet et al., 2005). In both treatments, all crop residues were left on the field. There were six plot pairs with very diverse 6-year crop rotations including winter wheat, winter barley, sugar beet, silage maize, summer oat, potato, rapeseed, pea (Pisum sativum L.), winter rye (Secale cereale L.), ley, summer oat, and soybean (Glycine $\max$ L.). The experiment Hausweid (Haus) was set up to test different tillage systems with a high loosening intensity (moldboard plough or chisel) compared to shallow and no tillage (Anken et al., 2004; Hermle et al., 2008). The 4-year crop rotation comprised winter wheat, winter rapeseed and silage maize. The experiment Burgrain (Burg) compares a conventional, an extensive and an organic farming system. They differ regarding plant protection and fertilization intensities (Zihlmann et al., 2010). The 6-year crop rotation included ley, winter wheat and barley. Before starting the experiment, the site was intensively fertilized with $\mathrm{P}$ and $\mathrm{K}$.

The experiment Balsthal (Bals) is a hay meadow that receives different mineral fertilizer treatments and is cut either twice or thrice a year, representing a relatively low $(2 \mathrm{x})$ to intermediate $(3 \mathrm{x})$ mowing frequency for the site's potential productivity (Thomet and Koch, 
Table 1

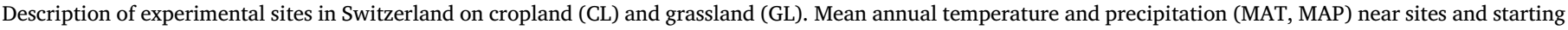
year of experiments are presented (years of SOC sampling in parentheses).

\begin{tabular}{|c|c|c|c|c|c|c|c|}
\hline $\begin{array}{l}\text { Name of experiment } \\
\text { (abbreviation) }\end{array}$ & Location & Landuse & $\begin{array}{l}\text { Altitude } \\
\text { (m a.s.l) }\end{array}$ & $\operatorname{MAT}\left({ }^{\circ} \mathrm{C}\right)$ & MAP (mm) & Start of experiment & $\begin{array}{l}\text { Latitude/ } \\
\text { Longitude }\end{array}$ \\
\hline ZOFE & Zurich & $\mathrm{CL}$ & 420 & 9 & 1040 & $\begin{array}{l}1949 \\
(1949-2009)\end{array}$ & $\begin{array}{l}47^{\circ} 25^{\prime} 37^{\prime \prime} \mathrm{N}, \\
8^{\circ} 31^{\prime} 10^{\prime \prime} \mathrm{E}\end{array}$ \\
\hline p29C & Changins & CL & 430 & 10.3 & 1009 & $\begin{array}{l}1969 \\
(1969-2005)\end{array}$ & $\begin{array}{l}46^{\circ} 23^{\prime} 56^{\prime \prime} \mathrm{N}, \\
6^{\circ} 14^{\prime} 30^{\prime \prime} \mathrm{E}\end{array}$ \\
\hline $\mathrm{p} 24 \mathrm{~A}$ & Changins & $\mathrm{CL}$ & 430 & 10.3 & 1009 & $\begin{array}{l}1976 \\
(1976-2009)\end{array}$ & $\begin{array}{l}46^{\circ} 24^{\prime} 01^{\prime \prime} \mathrm{N}, \\
6^{\circ} 13^{\prime} 46^{\prime \prime} \mathrm{E}\end{array}$ \\
\hline DOK & Therwil & CL & 300 & 9.7 & 791 & $\begin{array}{l}1978 \\
(1979-2005)\end{array}$ & $\begin{array}{l}47^{\circ} 30^{\prime} 10^{\prime \prime} \mathrm{N}, \\
7^{\circ} 32^{\prime} 23^{\prime \prime} \mathrm{E}\end{array}$ \\
\hline $\begin{array}{l}\text { Demo87 } \\
\text { ('Demo') }\end{array}$ & Zurich & CL & 420 & 9 & 1040 & $\begin{array}{l}1987 \\
(1990-2013)\end{array}$ & $\begin{array}{l}47^{\circ} 25^{\prime} 33^{\prime \prime} \mathrm{N}, \\
8^{\circ} 31^{\prime} 00^{\prime \prime} \mathrm{E}\end{array}$ \\
\hline $\begin{array}{l}\text { Hausweid } \\
\text { ('Haus') }\end{array}$ & Tänikon & $\mathrm{CL}$ & 540 & 8.3 & 1180 & $\begin{array}{l}1987 \\
(1987-2009)\end{array}$ & $\begin{array}{l}47^{\circ} 28^{\prime} 53^{\prime \prime} \mathrm{N}, \\
8^{\circ} 54^{\prime} 22^{\prime \prime} \mathrm{E}\end{array}$ \\
\hline $\begin{array}{l}\text { Burgrain } \\
\text { ('Burg') }\end{array}$ & Alberswil & CL & 520 & 8.5 & 1100 & $\begin{array}{l}1991-2008 \\
(1991-2006)\end{array}$ & $\begin{array}{l}47^{\circ} 08^{\prime} 20^{\prime \prime} \mathrm{N}, \\
7^{\circ} 59^{\prime} 31^{\prime \prime} \mathrm{E}\end{array}$ \\
\hline $\begin{array}{l}\text { Oberacker } \\
\text { ('Ober') }\end{array}$ & Zollikofen & CL & 550 & 9.1 & 1048 & $\begin{array}{l}1995 \\
(2002-2014)\end{array}$ & $\begin{array}{l}46^{\circ} 59^{\prime} 23^{\prime \prime} \mathrm{N}, \\
7^{\circ} 27^{\prime} 43^{\prime \prime} \mathrm{E}\end{array}$ \\
\hline $\begin{array}{l}\text { Balsthal } \\
\text { ('Bals') }\end{array}$ & Balsthal & GL & 930 & 5 & 1200 & $\begin{array}{l}1972 \\
(2002-2014)\end{array}$ & $\begin{array}{l}47^{\circ} 19^{\prime} 50^{\prime \prime} \mathrm{N}, \\
7^{\circ} 39^{\prime} 55^{\prime \prime} \mathrm{E}\end{array}$ \\
\hline Watt & Watt & GL & 500 & 9.5 & 1055 & $\begin{array}{l}1992 \\
(1997-2014)\end{array}$ & $\begin{array}{l}47^{\circ} 26^{\prime} 46^{\prime \prime} \mathrm{N}, \\
8^{\circ} 29^{\prime} 34^{\prime \prime} \mathrm{E}\end{array}$ \\
\hline $\begin{array}{l}\text { Oensingen } \\
\text { ('Oens') }\end{array}$ & Oensingen & GL & 450 & 9.5 & 1100 & $\begin{array}{l}2001 \\
(2001-2011)\end{array}$ & $\begin{array}{l}47^{\circ} 17^{\prime} 08^{\prime \prime} \mathrm{N}, \\
7^{\circ} 43^{\prime} 55^{\prime \prime} \mathrm{E}\end{array}$ \\
\hline
\end{tabular}

Table 2

Soil types and clay content for each experiment. Note that p29C includes plots that differ strongly regarding their clay content.

\begin{tabular}{lll}
\hline Experiment & Soil type (WRB) & Clay (\%) \\
\hline ZOFE & Haplic Luvisol & 14 \\
p29C & Calcaric Cambisol & $25 / 48$ \\
p24A & Calcaric Cambisol & 14 \\
DOK & Haplic Luvisol & 16 \\
Demo & Eutric Cambisol & 23 \\
Hausweid & Orthic Luvisol & 17 \\
Burgrain & Gleyic Cambisol & 18 \\
Oberacker & Eutric Cambisol & 15 \\
Balsthal & Clayic Cambisol & 16 \\
Watt & Loamic Cambisol & 22 \\
Oensingen & Eutri-Stagnic Cambisol & 43 \\
\hline
\end{tabular}

1993). In the experiment Watt all plots were cut 3 times per year. This represents a relatively low cutting frequency given the site's potential productivity (Liebisch et al., 2013). The plots received different amounts of mineral fertilizer. The experiment in Oensingen (Oens) compared two meadows under different management intensities (Ammann et al., 2007). The intensively managed field was typically cut four times per year and received mineral and organic fertilizer, whereas the extensive field received no fertilizer and was cut three times per year. Prior to the experiment, the site was under ley-arable rotation management. In total the effect of 80 different treatments on $\triangle \mathrm{SOC}$ were compared (Section 2.7).

\subsection{Determination of soil organic carbon content}

Soil organic C content in topsoil $(\sim 0-0.2 \mathrm{~m})$ was assessed by two different methods, depending on the experiment: 1) a modified K-dichromate oxidation method, using hot sulfuric acid (FAL, 1996) or 2) elemental analysis whereby SOC is oxidized in $\mathrm{O}_{2}$ and quantified as $\mathrm{CO}_{2}$ by GC-TCD (Gas chromatography with a thermal conductivity detector (Hekatech, Germany)). Elemental analysis recovers slightly more C than wet oxidation and we therefore applied a correction factor of 1.059 if SOC was determined by wet oxidation to allow comparing the different experiments (Oberholzer et al., 2014; Gubler et al., 2018).

\subsection{Calculation of soil organic carbon stocks}

For each experiment, the best possible method given the data available was used to calculate soil organic carbon stocks for topsoil ( $\sim 0-0.2 \mathrm{~m}$ depth): If $\mathrm{C}$ concentrations and bulk densities were measured for several layers, the equivalent soil mass approach described by Poeplau and Don (2013) was used. Otherwise, SOC stocks were calculated based on minimum equivalent soil masses (Ellert and Bettany, 1995; Lee et al., 2009). Both methods use dry mass for calculations. Accounting for different soil masses was especially important for experiments that included different tillage treatments (Haus, Ober, p29C) as these often affect bulk densities. For the experiment Burg bulk densities were estimated based on a pedotransfer function based on $\mathrm{C}_{\text {org }}$ (Oberholzer et al., 2014).

\subsection{Fertilization intensity}

To compare the effect of different fertilization treatments on SOC stock changes, we estimated their intensity based on a similar approach as Hirte et al. (2018a). We calculated the sum of fertilizer added as mineral NPK, plus how much NPK was mineralized from organic fertilizer. For this estimate NPK contents of manure of $1.5 / 0.9 / 6.0 \mathrm{~kg}$ $\mathrm{Mg}^{-1}$ and for undiluted slurry $2.7 / 0.6 / 6.3 \mathrm{~kg} \mathrm{~m}^{-3}$ were used (Richner and Sinaj, 2017). The ratio of amounts added relative to amounts recommended for specific crops to be applied in Switzerland (Richner and Sinaj, 2017) was calculated. A fertilization intensity of zero thus refers to an unfertilized treatment, one is equal to the recommended amount and anything above one is higher than recommended.

\subsection{Carbon inputs to soil}

The amount of annual plant $\mathrm{C}$ that was added to soil (including above ground residues (stubble, chaff, stover), roots, extra-root material from turnover and exudation) was estimated using an allometric equation modified from that of Bolinder et al. (2007). The original equation describes the amount of $\mathrm{C}$ input as a crop-specific, linear function of the measured harvest. However, a recent field study carried out in Switzerland on two of the sites included here (DOK, ZOFE) showed that belowground $C$ inputs of maize and winter wheat were constant, regardless of yields (Hirte et al., 2018b). We therefore used 


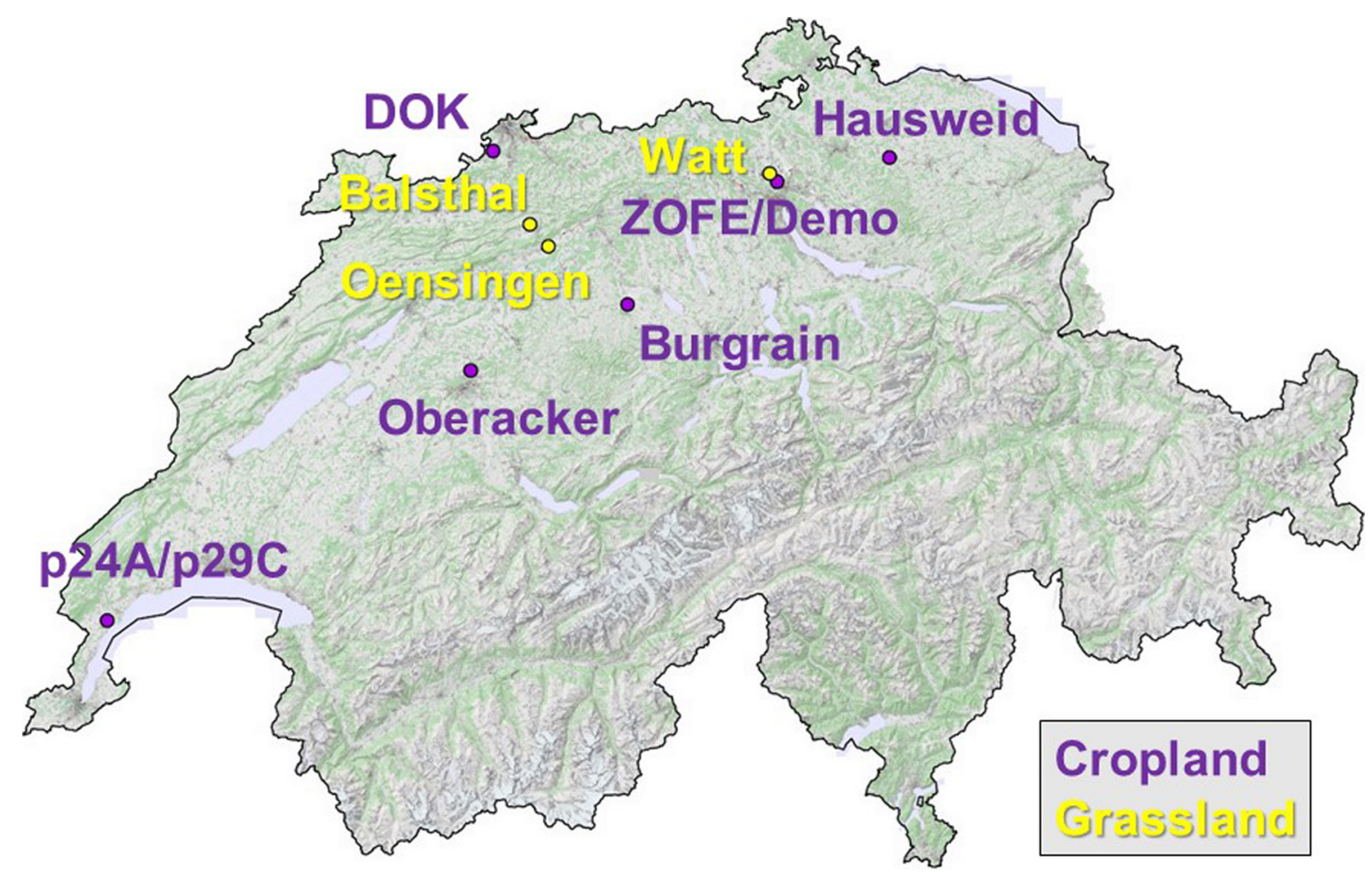

Fig. 1. Map of Switzerland showing location of 11 experimental sites.

these measured $\mathrm{C}$ inputs from roots and rhizodeposition. For small grain cereals (barley, oat, wheat), we used the value for winter wheat $\left(0.6 \mathrm{Mg} \mathrm{C} \mathrm{ha} \mathrm{yr}^{-1}\right)$. Values for grain maize were $0.46 \mathrm{Mg} \mathrm{C}$ $\mathrm{ha}^{-1} \mathrm{yr}^{-1}$ and for silage maize $1.1 \mathrm{Mg} \mathrm{Cha} \mathrm{hr}^{-1}$. In the case of other crops, belowground $\mathrm{C}$ inputs were scaled to a depth of $0-0.2 \mathrm{~m}$ as described in Keel et al. (2017). For permanent grassland and grass-clover ley in crop rotations, we used a constant soil C input $(2.27 \mathrm{Mg} \mathrm{C}$ ha $^{-1} \mathrm{yr}^{-1}$, Franko et al., 2011). This approach, though simplistic, was found to result in good model-data agreement for the site DOK (Keel et al., 2017).

Carbon inputs from organic fertilization (e.g. manure, slurry, compost) were either measured or calculated based on the assumption that manure contains $162 \mathrm{~kg} \mathrm{Mg}^{-1}$ organic matter (Richner and Sinaj, 2017) with a C content of $45 \%$. For slurry, an organic matter content of $67 \mathrm{~kg}$ $\mathrm{m}^{-3}$ (for undiluted slurry), C content of $45 \%$ and dilution of $1: 1$ with water were assumed. The annual average amounts applied are described in Table S1.

\subsection{Temperature change}

We calculated the temperature change for each individual site and across experimental years based on data measured on site or from weather stations nearby (Federal Office of Meteorology and Climatology MeteoSwiss, www.meteoswiss.admin.ch). At all sites, a temperature increase was recorded based on linear regressions ranging from $0.013{ }^{\circ} \mathrm{C} \mathrm{yr}^{-1}$ (Ober) to $0.069^{\circ} \mathrm{C} \mathrm{yr}^{-1}$ (DOK).

\subsection{Statistical analysis}

To compare different SOC trends, a linear regression was fitted to each treatment per site and the slope was used as a proxy for $\triangle \mathrm{SOC}$ ( $\mathrm{n}=80$ treatments), although fits were not always statistically significant $(\mathrm{P}<0.05)$. At site Haus, we also fitted an exponential decay function, due to a strong SOC decrease at the beginning of the experiment. However, the linear fit was better than the exponential function, supporting the use of the former (Fig. S1e).
The effect of different factors on $\triangle S O C$ was analyzed using a linear mixed effects model with site as a random factor (function lmer in $\mathrm{R}$ package lmerTest; Kuznetsova et al., 2017).

The following fixed factors were tested: fertilization intensity (F0F4.5), organic amendments other than crop residues (yes or no, e.g. manure, peat, green manure), clay content of soil (\%), initial SOC stock $\left(\mathrm{Mg} \mathrm{C} \mathrm{ha}{ }^{-1}\right.$ ), soil cover (average number of months per year across rotations based on crop-specific cover times), C inputs to soil (average sum of harvest residues plus other organic additions such as manure, peat etc. in $\mathrm{Mg} \mathrm{C} \mathrm{ha}{ }^{-1}$ ), land use (grassland or cropland), conversion from grassland to cropland prior to start of experiment (this was the case for sites ZOFE, Haus, Demo), management change (any changes that are expected to result in a loss of soil C, such as shifts from organic to mineral fertilization or drainage in addition to conversions from grassland to cropland (ZOFE, Haus, Demo, Watt, Ober, p29C)), organic (DOK, Burg) vs. conventional farming, and climatic conditions (mean annual temperature and precipitation, change in mean annual temperature (calculated as linear regression through mean annual temperatures)).

Factors that did not have a statistically significant effect on $\triangle \mathrm{SOC}$ in a full model were identified using backward selection (function step, $R$ package lmerTest) and were removed. This function does a backward elimination of random-effect terms followed by backward elimination of fixed-effect terms in linear mixed models. The two factors initial SOC stock and clay content were linearly related $\left(\mathrm{R}^{2}=0.56\right)$ based on visual inspection of scatter plots (function pairs in $\mathrm{R}$ package graphics, $\mathrm{R}$ Core Team 2018); the latter was excluded from further analysis because it had a lower F-value in the full model. The final model selected was $\Delta \mathrm{SOC} \sim \mathrm{C}$ input + soil cover + initial SOC $+(1 \mid$ site $)$. The residuals of this model and the random effect "site" were checked for normality and the variance was tested for heteroscedasticity. The variance explained by the entire model, including fixed and random effects, was calculated using the function r.squaredGLMM (R package MuMIn; Bartoń, 2018).

In addition to analysis of the whole data set, we analyzed a subset of treatments considered typical for Swiss agricultural systems and refer to these as 'common treatments'. These results should more closely reflect 


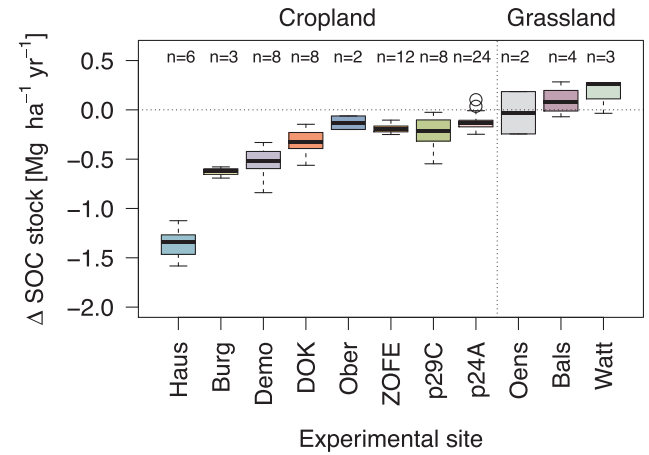

Fig. 2. Change in soil organic carbon stock of topsoil for eleven experimental field sites in Switzerland presented as boxplots. $n=2-24$ treatments per site.

on-farm situations. This subset only included cropland experiments since mineral fertilization on permanent grassland is not typical. Furthermore, we selected only those treatments receiving sufficient but not excessive NPK addition (fertilization intensity of 1-1.5; see above), and only those receiving all three nutrients. In total, the subset included 42 treatments (Table S1).

\section{Results}

Soil organic carbon stocks in topsoil $(\sim 0-0.2 \mathrm{~m})$ ranged from 33.6 to $76.7 \mathrm{Mg} \mathrm{C} \mathrm{ha}{ }^{-1}$ at the start of the experiments (Table S3). On average SOC stocks across 80 different treatments declined at a rate of $0.29 \mathrm{Mg} \mathrm{C} \mathrm{ha} \mathrm{yr}^{-1} \mathrm{yr}^{-1}$ The loss rate was slightly larger when sites were equally weighted $\left(0.30 \mathrm{Mg} \mathrm{C} \mathrm{ha-1} \mathrm{yr}^{-1} ; \mathrm{n}=11\right.$ sites (i.e. mean over treatments per site)). Site-to-site variability in $\triangle \mathrm{SOC}$ was considerable (Fig. 2, Table S3), with means ranging from SOC losses (-1.35 $\mathrm{Mg} \mathrm{C} \mathrm{ha}^{-1}$ $\mathrm{yr}^{-1}$, Haus) to small gains $\left(0.16 \mathrm{Mg} \mathrm{C} \mathrm{ha} \mathrm{yr}^{-1}\right.$, Watt). The average variance within sites was much smaller than between sites $(0.024 \mathrm{Mg} \mathrm{C}$ $\mathrm{ha}^{-1} \mathrm{yr}^{-1}$ vs $0.179 \mathrm{Mg} \mathrm{C} \mathrm{ha}^{-1} \mathrm{yr}^{-1}$ ).

The linear mixed effects model allowed to identify three fixed factors that had a significant effect on $\triangle$ SOC (Table 3): C inputs to soil (Fig. 3), soil cover (Fig. 4) and initial SOC stock (Fig. 5). The final model explained $95 \%$ of the variance in $\Delta$ SOC between treatments. While $\triangle$ SOC was positively related to C input and soil cover, it was negatively related to initial SOC (i.e. higher SOC losses at higher initial SOC, Table 3). At most sites, C inputs and $\triangle$ SOC were similar between different treatments (e.g. for sites Haus, Burg; Fig. 3), although for experiments DOK and $\mathrm{p} 24 \mathrm{~A}, \mathrm{C}$ inputs spanned a large range, and were linearly correlated with $\triangle \mathrm{SOC}$, demonstrating the importance of this factor $\left(\mathrm{R}^{2}=0.78\right.$ and $\mathrm{R}^{2}=0.71$ for DOK and $\mathrm{p} 24 \mathrm{~A}$ respectively). At both sites, the large range in $C$ inputs was the result of a gradient in plant-derived C (yields and thus harvest residues differed) plus a large variation in organic C amendments from e.g. fertilizer or cover crops (Table S1). Crop rotations, use of cover crops and type of tillage mainly determined the duration of soil cover. Soils under permanent grassland (Oens, Bals, Watt) and no-till (one treatment each at sites Haus, Ober) that were covered year-round with plants or crop residues on the surface showed smaller soil C losses (Fig. 4). One exception was the no-till treatment at Haus, a site where SOC losses were consistently larger than

\section{Table 3}

Results of linear mixed effects model (Standard error (SE), degrees of freedom (df)). All three fixed factors had a statistically significant effect on changes in SOC stocks.

\begin{tabular}{llllll}
\hline & Estimate & SE & df & t-value & P-value \\
\hline Intercept & -0.750 & 0.245 & 66.4 & -3.06 & $3.17 \mathrm{E}-03$ \\
C input & 0.128 & 0.021 & 66.8 & 6.12 & $5.63 \mathrm{E}-08$ \\
Soil cover & 0.058 & 0.018 & 70.3 & 3.17 & $2.25 \mathrm{E}-03$ \\
Initial SOC stock & -0.008 & 0.002 & 72.9 & -4.33 & $4.61 \mathrm{E}-05$ \\
\end{tabular}

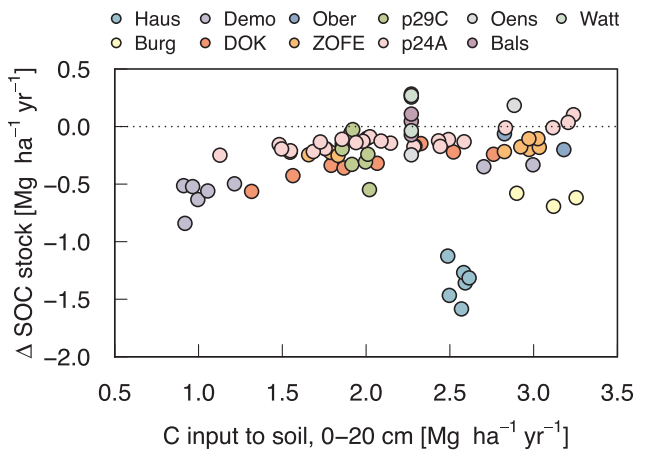

Fig. 3. Changes in topsoil SOC stocks were positively related to soil C inputs from plants and organic amendments (e.g. farmyard manure) ( $n=80$ treatments).

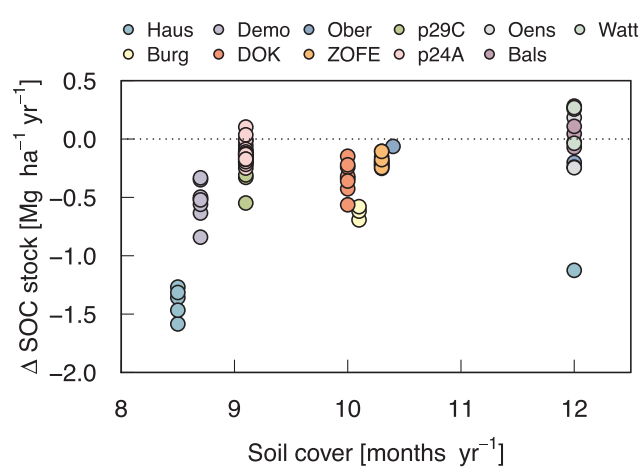

Fig. 4. Changes in topsoil SOC stocks increased with duration of soil cover $(n=80$ treatments).

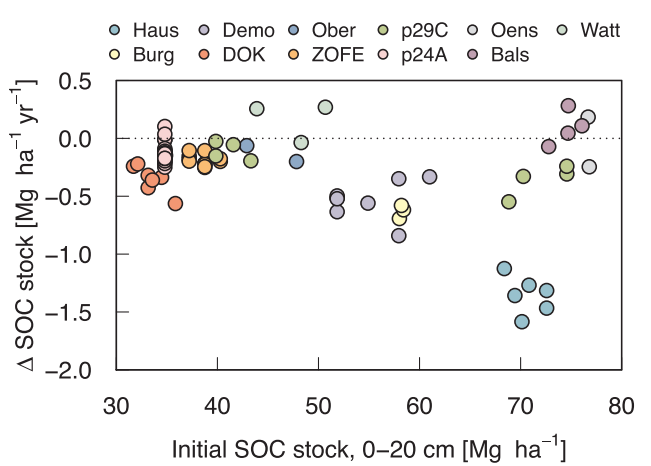

Fig. 5. Changes in topsoil SOC stocks were negatively related to mass-corrected initial SOC stocks ( $\mathrm{n}=80$ treatments).

at other sites, most likely due to a prior land-use change (see below). For other sites, respectively treatments at Haus and Ober, soil cover ranged from 8.5 to 10.5 months and was mostly the same within each site because crop rotations were identical for all treatments within each site. Except for sites Haus and Burg, high initial SOC stocks were associated with high clay content (Fig. S2). High initial SOC stocks at Haus are most likely a legacy of the former permanent grassland. To test whether the outcome of our analysis was driven by pronounced SOC losses at site Haus, we carried out the same tests without data from this site. All factors remained statistically significant, though the statistical significance of soil cover was reduced $(\mathrm{P}=0.039)$ and the model explained only $91 \%$ of the variance in $\triangle S O C$ between treatments. If all sites that experienced a grassland to cropland conversion were excluded, the factor soil cover was only marginally significant $(P=0.09$ ), but a difference in $\triangle \mathrm{SOC}$ was found between grassland and cropland sites $(\mathrm{P}<0.01)$, with cropland sites losing more SOC than grasslands.

For a subset of the data, including only treatments typically 


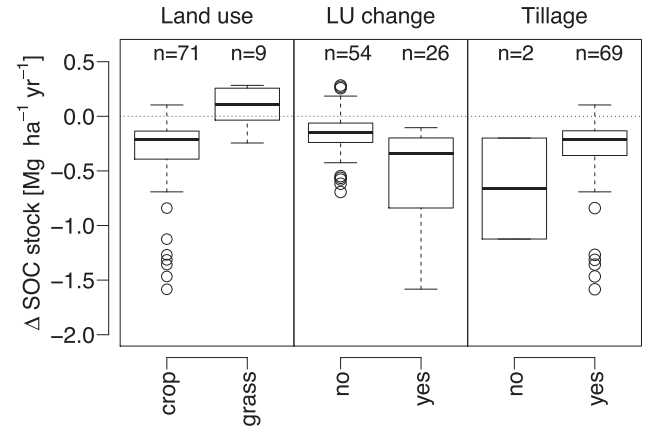

Fig. 6. Land use, land-use change prior to start of experiment and tillage (only cropland experiments shown) did not have a significant effect on $\Delta S O C$.

practiced in Switzerland, four fixed factors had a significant effect on $\triangle$ SOC: organic additions (whether or not any organic material was applied in addition to harvest residues), soil cover (number of months), clay content and mean annual temperature. Thus, with exception of the variable temperature, the same or very similar factors (organic additions are related to $\mathrm{C}$ inputs and clay content was linearly related to initial SOC stocks) were found to drive SOC changes for this subset of treatments. The range of $\triangle S O C$ at each site was somewhat narrower, but the overall picture did not change much (Fig. S3).

Permanent grasslands tended to lose less or even gain SOC (mean $\Delta$ SOC: $0.09 \mathrm{Mg} \mathrm{C} \mathrm{ha}{ }^{-1} \mathrm{yr}^{-1}$ ) compared to croplands (mean $\Delta$ SOC: $-0.34 \mathrm{Mg} \mathrm{C} \mathrm{ha}{ }^{-1} \mathrm{yr}^{-1}$; Figs. 2 and 6 ('Land use')). On sites that were converted from grassland to cropland (i.e. sites that experienced a landuse change) just before the start of the experiment, soils tended to lose more $\mathrm{C}$ than on sites with a constant land use, but the difference was not statistically significant (Fig. 6). If the three converted sites were excluded, we found a significant effect of land-use, while soil cover was no longer significant. Initial SOC stocks and C inputs remained significant. Contrary to expectations, two cropland soils that were not tilled tended to lose more $\mathrm{C}$ than normally tilled soils and plots with shallow tillage (Fig. 6).

Among all 80 treatments investigated, there was no treatment with a statistically significant increase in SOC. Six out of eight treatments that tended to show a positive soil $\mathrm{C}$ balance were on permanent grassland and two were heavily fertilized croplands (Fig. 7, FYM70-105 and FYM70-70 in Table S1). With increasing fertilization intensity there was a tendency for lower SOC losses or even small gains (Fig. 7). Organic additions tended to have a positive influence on the SOC balance, though this factor was not statistically significant. There was no trend in $\triangle$ SOC depending on the fraction of ley.

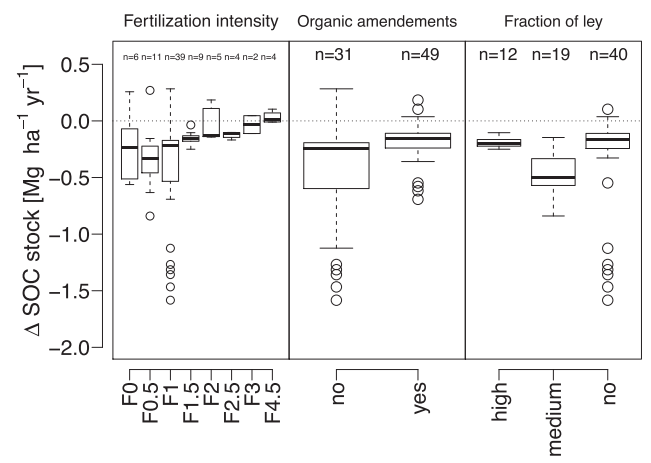

Fig. 7. Changes in SOC stocks were not significantly affected by fertilization intensities, organic amendments (e.g. manure, straw) or fraction of ley in the rotation (only cropland experiments). Fertilization intensities are expressed relative to Swiss guidelines and present averages across crop rotations. $\mathbf{F}_{\mathbf{0}}$ unfertilized, $\mathbf{F}_{\mathbf{0 . 5}}:$ half, $\mathbf{F}_{\mathbf{1}}$ : normal, $\mathbf{F}_{\mathbf{1 . 5}}:$ 1.5-times, $\mathbf{F}_{\mathbf{2}}$ : double, $\mathbf{F}_{\mathbf{2 . 5}}:$ 2.5-times, $\mathbf{F}_{\mathbf{3}}$ : 3-times $\mathbf{F}_{4.5}$ : 4.5-times (recommended fertilization intensity).

\section{Discussion}

Soil organic carbon stocks of mineral topsoils $(\sim 0-0.2 \mathrm{~m})$ mostly decreased in eleven Swiss agricultural field experiments carried out over the last decades (mean: $-0.29 \mathrm{Mg} \mathrm{Cha} \mathrm{hr}^{-1}$ ). If only treatments common in practice were considered, the loss was even higher (-0.40 Mg C ha $\left.{ }^{-1} \mathrm{yr}^{-1}\right)$. Two recent studies carried out in Switzerland, but based on very different approaches support our findings. Using eddy covariance measurements, Emmel et al. (2018) reported losses in SOC of $16-19 \%$ during 13 years for a crop field adjacent to site Oens; these correspond to an annual decrease in SOC of -1.1 to $-1.3 \mathrm{Mg} \mathrm{C} \mathrm{ha}{ }^{-1}$ $\mathrm{yr}^{-1}$. Also Stumpf et al. (2018) documented a decrease in SOC for cropland (without ley in the rotation) based on a combination of spectral imagery and a random forest model. Nevertheless, the widespread SOC losses we found are unexpected, as several practices assumed to enhance SOC stocks, such as organic fertilization (Poulton et al., 2018), incorporation of crop residues (Buyanovsky and Wagner, 1998; Kong et al., 2005), and complex crop rotations with grass-clover leys (Johnston et al., 2009) were among the 80 different treatments.

\subsection{Potential explanations for soil organic carbon losses}

Firstly, estimated C inputs to the soil were rather low. The sum of C added to topsoil from plant residues and organic additions ranged from 0.91 to $3.25 \mathrm{Mg} \mathrm{C} \mathrm{ha}{ }^{-1} \mathrm{yr}^{-1}$ (mean: $2.2 \mathrm{Mg} \mathrm{C} \mathrm{ha}^{-1} \mathrm{yr}^{-1}$, up to $65 \%$ from organic additions) and was similar when only common practices were considered (1.21 to $3.25 \mathrm{Mg} \mathrm{C} \mathrm{ha}^{-1} \mathrm{yr}^{-1}$; mean: $2.3 \mathrm{Mg} \mathrm{C} \mathrm{ha}^{-1}$ $\mathrm{yr}^{-1}$ ). Studies in Europe or the U.S. that documented SOC enhancements reported annual C inputs between $5.4 \mathrm{Mg} \mathrm{C}^{-1}$ and $8.9 \mathrm{Mg} \mathrm{C}$ $\mathrm{ha}^{-1}$ (Buyanovsky and Wagner, 1998; Kong et al., 2005; Autret et al., 2016). Most likely C inputs in these studies were higher due to incorporation of cereal straw, which is an uncommon practice in Switzerland. Furthermore, $\mathrm{C}$ inputs through organic fertilization were also comparatively low in our studies. For example, the Hoosfield Continuous Barley experiment and the Broadbalk Winter Wheat experiment in Rothamsted (UK) both have treatments that receive around $3 \mathrm{Mg}$ FYM-C ha ${ }^{-1} \mathrm{yr}^{-1}$ (Poulton et al., 2018), which is twice as much as the FYM treatment at site Demo that follows Swiss guidelines, but lower than the highest fertilization rates at p24A (Maltas et al., 2018).

Secondly, initial SOC stocks were relatively high (cropland: $44.3 \mathrm{Mg}$ $\mathrm{C}$ ha $^{-1}$; grassland: $66.1 \mathrm{Mg} \mathrm{C} \mathrm{ha}{ }^{-1}$ ) compared to the Swiss mean (40.6 Mg C ha ${ }^{-1}$ for cropland and $50.7 \mathrm{Mg} \mathrm{C} \mathrm{ha}^{-1}$ for grassland (Leifeld et al., 2005)) and soils might therefore be prone to C losses (Johnston et al., 2009; Kätterer et al., 2013). While high initial SOC stocks can partly be explained by high clay contents (Fig. S2; Johnston et al., 2009), they are also a legacy of former land use. In our dataset, three cropland sites were converted from permanent grassland before the experiments started (Demo, ZOFE, and Haus). Grasslands commonly have higher SOC stocks (Leifeld et al., 2009) and after conversion, stocks decrease as the system moves towards a lower SOC equilibrium state (Poeplau et al., 2011). This could be shown for sites Haus (Hermle et al., 2008) and ZOFE (Oberholzer et al., 2014) where higher SOC stocks were measured on adjacent grasslands. An alternative explanation for high initial C stocks is that soils were previously wet and might have accumulated $\mathrm{C}$ through incomplete (anaerobic) decomposition. We checked historic maps for every prior decade back to the year 1860, but could not find any indications for wetlands for any of the studied sites (Table S2). Nevertheless, p29C is situated on drained soil, suggesting it was previously wet, which could partly explain why some of the plots had high initial SOC stocks.

Thirdly, increasing temperatures could have led to higher SOC losses (Crowther et al., 2016; Bellamy et al., 2005), through increased soil respiration rates (i.e. $\mathrm{CO}_{2}$ losses), since Switzerland is strongly affected by recent climate change (Begert and Frei, 2018). However, although air temperatures have increased at all sites during the duration of the experiments, these temperature changes were not significant 
factors in our analysis. This is in line with previous studies where other factors such as changes in management had a more pronounced influence on SOC declines than temperature increases (Smith et al., 2007; Leifeld et al., 2009). For the subset of data representative of typical agricultural practices, we found a relationship with climatic conditions: SOC losses were larger at mean annual temperatures below $9{ }^{\circ} \mathrm{C}$, suggesting that cooler sites are more prone to $\mathrm{C}$ losses. Temperature increases however, did not explain this pattern, as they were lower at cooler sites $\left(0.028^{\circ} \mathrm{C} \mathrm{yr}^{-1}\right)$ than at sites with mean annual temperatures of $9^{\circ} \mathrm{C}$ or above $\left(0.036{ }^{\circ} \mathrm{C} \mathrm{yr}{ }^{-1}\right)$.

In summary, low $\mathrm{C}$ inputs and in case of some sites, former land-use conversions, are most likely explanations for the observed decreases in SOC. The fact that plant-derived $\mathrm{C}$ inputs and other organic $\mathrm{C}$ additions were identified as drivers for SOC changes in our analysis, is in line with this conclusion and earlier studies for sites DOK (Leifeld et al., 2009) and ZOFE (Oberholzer et al., 2014) as well as a global meta-analysis (Han et al., 2016).

However, why were $C$ inputs so low despite the use of practices expected to increase them? Compared to a study in France (Autret et al., 2016), Swiss experiments only assessed the effect of one or two such practices at once. In contrast, Autret et al. (2016) combined several: crop residues (including wheat straw) and the whole aboveground biomass of cover crops (Alfalfa and fescue) as well as catch crops (oat, vetch, white mustard and fodder radish) were left on the field, and crop diversity was high. Furthermore, the soil was covered continuously. In sum, these practices led to high C inputs of $5.41 \mathrm{Mg} \mathrm{ha}{ }^{-1} \mathrm{yr}^{-1}$, dominated by straw $\left(1.84 \mathrm{Mg} \mathrm{C} \mathrm{ha}{ }^{-1} \mathrm{yr}^{-1}\right)$, and an associated SOC increase of $0.63 \mathrm{Mg} \mathrm{ha}^{-1} \mathrm{yr}^{-1}$. Leaving the entire biomass of Alfalfa on the field - which contributed $1.12 \mathrm{Mg} \mathrm{C} \mathrm{ha}{ }^{-1} \mathrm{yr}^{-1}$ to their total inputs - is however not a regular agricultural practice. Other studies from the U.S. also showed that cereal straw residues contribute significant amounts of C (1-2 $\mathrm{Mg} \mathrm{ha}^{-1} \mathrm{yr}^{-1}$ ) (Buyanovsky and Wagner, 1998; Kong et al., 2005). Because this is an uncommon practice in Switzerland, it was only tested at three sites (p24A, Haus, Ober) with negligible to moderate effects although added amounts of $\mathrm{C}$ were large $(3.8 \mathrm{Mg} \mathrm{C}$ $\mathrm{ha}^{-1} \mathrm{yr}^{-1}$ for cereal straw at site Ober). At site p24A cereal straw retention led to slight decreases in yield (and possibly lower $\mathrm{C}$ inputs from residues) (Maltas et al., 2018) most likely due to reduced availability of $\mathrm{N}$ for plants. This could explain why SOC did not increase in response to straw additions.

Based on our analysis we cannot identify the main drivers of $\triangle S O C$ for each site, but broad patterns of $\triangle \mathrm{SOC}$ offer some indications. Given the much smaller within than between site variability, we conclude that site-specific factors including site history have a stronger effect on $\triangle S O C$ than the actual management. For example, a combination of former land use conversion and high initial SOC content are the most likely explanations for dramatic C losses at site Haus. At ZOFE and Demo, initial SOC stocks were not as high relative to the clay content (Fig. S2), despite grassland-to-cropland conversions, offering a potential explanation for more moderate losses compared to Haus. Within sites, gradients in $\triangle \mathrm{SOC}$ are probably driven by gradients in $\mathrm{C}$ inputs as indicated by linear relationships for sites p24A and DOK (Fig. 3). An exception is site $\mathrm{p} 29 \mathrm{C}$, where differences of $\triangle S O C$ seem to be dominated by pronounced differences in initial SOC stocks because of large variations in soil texture within the field (Fig. S2).

\subsection{Improvement of SOC in Swiss agricultural systems}

Based on our analysis we have identified three factors that are critical for SCS: C inputs, soil cover and initial SOC stocks (i.e. a site characteristic). In the following section, we will discuss potential options to enhance SOC in Swiss agricultural systems related to these.

Firstly, crop rotations can be optimized to increase plant derived C inputs. This can be achieved by planting crops that contribute high amounts of residues and by leaving as much of them on the field. Crops with high fractions of residues are grain corn or grass-clover leys. Root crops such as sugar beet or potatoes have very small amounts of residues. According to the information available for Switzerland, residues are generally left on the field except for cereal straw (Swiss AgriEnvironmental Data Network). Cereal straw is typically used for animal bedding (Federal Statistical office; https://www.bfs.admin.ch) and returned to the field together with manure. In terms of the $\mathrm{C}$ balance, it is not clear whichever option is more profitable. During storage of manure, significant amounts of $\mathrm{C}$ are lost through respiration (Sommer and Hutchings, 2001; Shah et al., 2016), due to a lack of a stabilising soil matrix. Possibly, less C would be lost if cereal straw would be left on the field and only slurry would be returned. Multi-cropping (undersowing/intercropping/double cropping) might be another option to enhance plant C inputs (Cong et al., 2014). Furthermore, deep rooting cultivars with higher belowground C inputs could be planted (Kell, 2011).

Based on data from Switzerland's national GHG inventory, the amount of organic fertilizer generated in Switzerland is lower than the amount that could be distributed based on the Swiss fertilization guidelines. Most likely, this gap is filled by mineral fertilizer, which could partly be complemented with straw to improve the soil C balance (Sinaj and Jeangros, 2019). According to this study, green manure in combination with mineral fertilizer was not as efficient. Compost from urban waste or the solid phase from biogas plants might be other options to enhance $\mathrm{C}$ inputs. Yearly about 350 '000 Mg d.m. are applied in Swiss agriculture (Kupper et al., 2018) but there is potential to increase the production of these so-called recycling fertilizers (Mandaliev and Schleiss, 2016). Generally, the transfer of C between different systems has to be assessed carefully, as C added to agricultural soils can be lacking elsewhere.

Secondly, soil cover can be increased by an optimized rotation including winter and summer crops. Additionally cover crops can be planted, which have several advantages. They reduce $\mathrm{NO}_{3}$-leaching, may decrease $\mathrm{N}_{2} \mathrm{O}$-losses (Basche et al., 2014), and are not associated with yield reductions, as is the case for extensification. Globally the SCS potential is estimated to be $0.12 \mathrm{Pg} \mathrm{C} \mathrm{yr}^{-1}$ (Poeplau and Don, 2015) and a Swiss study indicated a positive effect on SOC (Büchi et al., 2018). Due to former incentives, cover crops are already partly used in Switzerland, but most likely this practice could be intensified. To strengthen the positive influence on the SOC balance of practices described above, they could be combined as was presented by Autret et al. (2016). In typical Swiss farming systems, it should for example be possible to combine cover crops with residue retention (for non-cereals) and organic fertilization.

From a soil $\mathrm{C}$ perspective, converting cropland to permanent grassland would be an option to sequester C (Figs. 2 and 6). Due to lower disturbance (no ploughing), that leads to protection of soil through aggregation, higher belowground $\mathrm{C}$ inputs and a permanent soil cover, grasslands usually store more SOC than croplands (Leifeld et al., 2005). Unfortunately two of the three grassland sites studied here received only mineral fertilizer for experimental purposes (Bals, Watt), which is very uncommon for grassland managed by farmers in Switzerland. If organic fertilizer had been applied, these sites might have sequestered more C. Several lines of evidence suggest that soils under permanent grassland in Switzerland are either $\mathrm{CO}_{2}$ neutral (FOEN, 2019) or are small $\mathrm{CO}_{2}$ sinks $\left(0.33-2.7 \mathrm{t} \mathrm{C} \mathrm{ha}^{-1} \mathrm{yr}^{-1}\right.$ for intensively

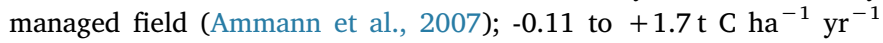
(Zeeman et al., 2010)).

For the same reasons just discussed for permanent grasslands, increasing the fraction of ley in crop rotations might be an efficient measure to sequester more C (Börjesson et al., 2018; Persson et al., 2008; Poeplau et al., 2015) although this was not a statistically significant factor in our analysis (Fig. 7). In Switzerland, ley could be used to partly replace silage maize which, after ley, is the most important fodder crop grown, covering a tenth of the agricultural area (about $43^{\prime} 000 \mathrm{ha}$ ). Since the 1990s, the area of ley has increased from about $100^{\prime} 000$ to $125^{\prime} 000$ ha and silage maize from $39^{\prime} 000$ to $47^{\prime} 000$ ha, 
without a clear effect on the overall SOC stocks (FOEN, 2019).

Regarding the effect of no-till on SCS, we cannot make any firm conclusion based on the few data included in our analysis. However, Luo et al. (2010) and Powlson et al. (2014) showed that no-till only leads to a change in the distribution of $\mathrm{C}$ with depth. In subsoil, SOC increases, while at lower depth SOC decreases, resulting in zero effects over the whole profile. This was also confirmed for sites Ober and p29C (Martínez et al., 2016; Büchi et al., 2017).

Thirdly, because high initial stocks were accompanied with larger losses, we suggest concentrating described efforts on fields with rather low SOC stocks. To decide which practices could be applied to improve the soil C balance, it is important to evaluate them in a whole system approach. In other words, it is critical to know whether the practice might have negative side effects (e.g. fertilization can lead to $\mathrm{N}_{2} \mathrm{O}$ emissions) and whether farmers would implement them (e.g. are they expensive, do they reduce yields, are they labor intensive?). Cover crops generally seem a very promising practice, as they have no GHG emission trade-offs and are not very expensive.

Although practices discussed so far might enhance SOC stocks in Switzerland, these measures will probably not be sufficient to sequester the required amounts of $C$ to reach the goal of the 4 per 1000 initiative (0.2 Mg C ha ${ }^{-1} \mathrm{yr}^{-1}$ for cropland and $0.25 \mathrm{Mg} \mathrm{ha}^{-1} \mathrm{yr}^{-1}$ for grassland). Yet, there are other promising practices that may be introduced. The application of biochar has been widely discussed in the literature and has often shown beneficial effects on soil C storage and mainly in the tropics, also on soil fertility and yields (Lehmann, 2007; Smith, 2016). Adding biochar has the advantage of being less prone to reversibility compared to other SCS measures, owing to the inherently higher stability of biochar as compared to other organic inputs. Currently the greatest disadvantage is the high cost. However, the Swiss agricultural system is strongly dependent on subsidies and methods to improve SCS, could be promoted through payments. Deep ploughing, a method used to improve soil structure, has been shown to increase SOC stocks by very significant amounts (Alcantara et al., 2016, 2017; Schiedung et al., 2019). Nevertheless, to date, these studies remain the only ones we know of and thus the generality of this approach, as well as further ecological implications must be explored in more detail. Recent studies, suggest that agroforestry has the potential to sequester C also in Switzerland (Kay et al., 2018). Various combinations of woody plants and crops or grasslands exist. Traditional combinations in Switzerland are cherry orchards and pastures. More innovative combinations are $\mathrm{Po}$ pulus tremula as energy crops combined with maize or sorghum; apple trees combined with wheat and strawberry fields (Kuster et al., 2012). Agroforestry systems come along with many co-benefits such as increased total productivity per area land, reduced soil erosion, less nutrient and pesticide leaching or increases in biodiversity (Kaeser et al., 2010).

Based on a summary of eleven long-term experiments we show that agricultural practices subsidized under the 'Proof of Ecological Performance' in Switzerland, are not sufficient to sustain organic carbon stocks in cropland topsoils. We suggest to intensify these practices as they are important to prevent even larger C losses and often have many beneficial effects, such as improved water infiltration, aggregate stability and ease of tillage (Blair et al., 2006; Chervet et al., 2006). Based on our results we conclude that it will be necessary to 1) combine several SOC enhancing practices to sequester significant amounts of C in Swiss agricultural soils and 2) test novel measures such as the application of biochar, deep soiling or agroforestry.

\section{Declaration of Competing Interest}

None.

\section{Acknowledgements}

Robin Giger is acknowledged for soil sampling, sample preparation and elemental analysis. We thank Lucie Gunst for providing the data from the DOK experiment, Hansrudolf Oberholzer for the data from the ZOFE experiment, Thomas Keller for bulk density data and Moritz Müller for soil C content measurements of the Oberacker experiment.

\section{Appendix A. Supplementary data}

Supplementary material related to this article can be found, in the online version, at doi:https://doi.org/10.1016/j.agee.2019.106654.

\section{References}

Alcantara, V., Don, A., Vesterdal, L., Well, R., Nieder, R., 2017. Stability of buried carbon in deep-ploughed forest and cropland soils - implications for carbon stocks. Sci. Rep. 7 5511-5511.

Alcantara, V., Don, A., Well, R., Nieder, R., 2016. Deep ploughing increases agricultural soil organic matter stocks. Glob. Chang. Biol. 22, 2939-2956.

Ammann, C., Flechard, C.R., Leifeld, J., Neftel, A., Fuhrer, J., 2007. The carbon budget of newly established temperate grassland depends on management intensity. Agric. Ecosyst. Environ. 121, 5-20.

Anken, T., Weisskopf, P., Zihlmann, U., Forrer, H., Jansa, J., Perhacova, K., 2004. Longterm tillage system effects under moist cool conditions in Switzerland. Soil Tillage Res. 78, 171-183.

Autret, B., Mary, B., Chenu, C., Balabane, M., Girardin, C., Bertrand, M., Grandeau, G., Beaudoin, N., 2016. Alternative arable cropping systems: a key to increase soil organic carbon storage? Results from a 16 year field experiment. Agric. Ecosyst. Environ. 232, 150-164.

Bartoń, K., 2018. MuMIn: Multi-Model Inference. R Package Version 1.42.1. https:// CRAN.R-project.org/package = MuMIn.

Basche, A.D., Miguez, F.E., Kaspar, T.C., Castellano, M.J., 2014. Do cover crops increase or decrease nitrous oxide emissions? A meta-analysis. J. Soil Water Conserv. 69, $471-482$.

Begert, M., Frei, C., 2018. Long-term area-mean temperature series for SwitzerlandCombining homogenized station data and high resolution grid data. Int. J. Climatol. 38, 2792-2807.

Bellamy, P.H., Loveland, P.J., Bradley, R.I., Lark, R.M., Kirk, G.J.D., 2005. Carbon losses from all soils across England and Wales 1978-2003. Nature 437, 245-248.

Blair, N., Faulkner, R.D., Till, A.R., Korschens, M., Schulz, E., 2006. Long-term management impacts on soil C, N and physical fertility - Part II: Bad Lauchstadt static and extreme FYM experiments. Soil Tillage Res. 91, 39-47.

Bolinder, M.A., Janzen, H.H., Gregorich, E.G., Angers, D.A., VandenBygaart, A.J., 2007. An approach for estimating net primary productivity and annual carbon inputs to soil for common agricultural crops in Canada. Agric. Ecosyst. Environ. 118, 29-42.

Börjesson, G., Bolinder, M.A., Kirchmann, H., Kätterer, T., 2018. Organic carbon stocks in topsoil and subsoil in long-term ley and cereal monoculture rotations. Biol. Fertil. Soils 54, 549-558.

Büchi, L., Wendling, M., Amosse, C., Jeangros, B., Sinaj, S., Charles, R., 2017. Long and short term changes in crop yield and soil properties induced by the reduction of soil tillage in a long term experiment in Switzerland. Soil Tillage Res. 174, 120-129.

Büchi, L., Wendling, M., Amosse, C., Necpalova, M., Charles, R., 2018. Importance of cover crops in alleviating negative effects of reduced soil tillage and promoting soil fertility in a winter wheat cropping system. Agric. Ecosyst. Environ. 256, 92-104.

Buyanovsky, G.A., Wagner, G.H., 1998. Carbon cycling in cultivated land and its global significance. Glob. Chang. Biol. 4, 131-141.

Chervet, A., Ramseier, L., Sturny, W.G., 2005. Direktsaat und Pflug im 10-jährigen Systemvergleich. Agrarforschung 12, 184-189.

Chervet, A., Ramseier, L., Sturny, W.G., Weisskopf, P., Zihlmann, U., Müller, M., Schaffluitzel, R., 2006. Bodenwasser bei Direktsaat und Pflug. Agrarforschung 13, $162-169$.

Common Agricultural Policy towards, 2020. ANNEX 2 Greening the CAP, Commission Staff Working Paper. Impact Assessment, 2011.

Cong, W., Hoffland, E., Li, L., Six, J., Sun, J.H., Bao, X.G., Zhang, Fs., Van der Werf, W. 2014. Intercropping Enhances Soil Carbon and Nitrogen.

Crowther, T.W., Todd-Brown, K.E.O., Rowe, C.W., Wieder, W.R., Carey, J.C., Machmuller, M.B., Snoek, B.L., Fang, S., Zhou, G., Allison, S.D., Blair, J.M., Bridgham, S.D., Burton, A.J., Carrillo, Y., Reich, P.B., Clark, J.S., Classen, A.T., Dijkstra, F.A., Elberling, B., Emmett, B.A., Estiarte, M., Frey, S.D., Guo, J., Harte, J., Jiang, L., Johnson, B.R., Kroel-Dulay, G., Larsen, K.S., Laudon, H., Lavallee, J.M., Luo, Y., Lupascu, M., Ma, L.N., Marhan, S., Michelsen, A., Mohan, J., Niu, S., Pendall, E., Penuelas, J., Pfeifer-Meister, L., Poll, C., Reinsch, S., Reynolds, L.L., Schmidt, I.K., Sistla, S., Sokol, N.W., Templer, P.H., Treseder, K.K., Welker, J.M., Bradford, M.A., 2016. Quantifying global soil carbon losses in response to warming. Nature 540 $104-+$

Ellert, B.H., Bettany, J.R., 1995. Calculation of organic matter and nutrients stored in soils under contrasting management regimes. Can. J. Soil Sci. 75, 529-538.

Emmel, C., Winkler, A., Hörtnagl, L., Revill, A., Ammann, C., D’Odorico, P., Buchmann, N., Eugster, W., 2018. Integrated management of a Swiss cropland is not sufficient to preserve its soil carbon pool in the long term. Biogeosciences 15, 5377-5393.

FAL, 1996. Referenzmethoden der Eidg. landwirtschaftlichen Forschungsanstalten, Zürich-Reckenholz.

Fließbach, A., Oberholzer, H.-R., Gunst, L., Mäder, P., 2007. Soil organic matter and biological soil quality indicators after 21 years of organic and conventional farming. Agric. Ecosyst. Environ. 118, 273-284.

FOEN, 2019. Switzerland's greenhouse gas inventory 1990-2017. National Inventory Report.

Franko, U., Kolbe, H., Thiel, E., Ließ, E., 2011. Multi-site validation of a soil organic 
matter model for arable fields based on generally available input data. Geoderma 166, 119-134.

Fuss, S., Lamb, W.F., Callaghan, M.W., Hilaire, J., Creutzig, F., Amann, T., Beringer, T., Garcia, Wd.O., Hartmann, J., Khanna, T., Luderer, G., Nemet, G.F., Rogelj, J., Smith, P., Vicente, J.L.V., Wilcox, J., Dominguez, Md.M.Z., Minx, J.C., 2018. Negative emissions-Part 2: costs, potentials and side effects. Environ. Res. Lett. $1363002-$ 63002.

Gubler, A., Wächter, D., Schwab, P., 2018. Homogenisierung von BodenkohlenstoffDaten: Harmonisierung der Resultate aus Nassoxidation (FAL-Methode) und Trockenveraschung. Agroscope Sci. 62, 1-9.

Han, P., Zhang, W., Wang, G., Sun, W., Huang, Y., 2016. Changes in soil organic carbon in croplands subjected to fertilizer management: a global meta-analysis. Sci. Rep. 6 27199-Article No.: 27199.

Hermle, S., Anken, T., Leifeld, J., Weisskopf, P., 2008. The effect of the tillage system on soil organic carbon content under moist, cold-temperate conditions. Soil Tillage Res. 98, 94-105.

Hirte, J., Leifeld, J., Abiven, S., Mayer, J., 2018a. Maize and wheat root biomass, vertical distribution, and size class as affected by fertilization intensity in two long-term field trials. Field Crops Res. 216, 197-208.

Hirte, J., Leifeld, J., Abiven, S., Oberholzer, H.-R., Mayer, J., 2018b. Below ground carbon inputs to soil via root biomass and rhizodeposition of field-grown maize and wheat at harvest are independent of net primary productivity. Agric. Ecosyst. Environ. 265, $556-566$.

IPCC, 2018. Summary for policymakers. In: Masson-Delmotte, V., Zhai, P., Pörtner, H.-O., Roberts, D., Skea, J., Shukla, P.R., Pirani, A., Moufouma-Okia, W., Péan, C., Pidcock, R., Connors, S., Matthews, J.B.R., Chen, Y., Zhou, X., Gomis, M.I., Lonnoy, E., Maycock, T., Tignor, M., Waterfield, T. (Eds.), Global Warming of $1.5^{\circ} \mathrm{C}$, An IPCC Special Report on the impactsof global warming of $1.5^{\circ} \mathrm{C}$ above pre-industrial levels and related global greenhouse gas emission pathways,in the context of strengthening the global response to the threat of climate change, sustainable development,and efforts to eradicate poverty. In press.

Johnston, A.E., Poulton, P.R., Coleman, K., 2009. Soil organic matter: its importance in sustainable agriculture and carbon dioxide fluxes. Adv. Agron. 101, 1-57 Elsevier Academic Press Inc, San Diego.

Kaeser, A., Palma, J., Firesenai, S., Herzog, F., 2010. Umweltleistungen von Agroforstwirtschaft. ART-Bericht 736, 1-3.

Kätterer, T., Bolinder, M.A., Thorvaldsson, G., Kirchmann, H., 2013. Influence of leyarable systems on soil carbon stocks in Northern Europe and Eastern Canada. Grassland science in Europe. Organising Committee of the 17th Symposium of the European Grassland Federation 2013 and Agricultural University of Iceland (AUI), Reykjavík 47-56.

Kay, S., Crous-Duran, J., Ferreiro-Dominguez, N., de Jalon, S.G., Graves, A., Moreno, G., Rosa Mosquera-Losada, M., Palma, J.H.N., Roces-Diaz, J.V., Javier SantiagoFreijanes, J., Szerencsits, E., Weibel, R., Herzog, F., 2018. Spatial similarities between European agroforestry systems and ecosystem services at the landscape scale. Agrofor. Syst. 92, 1075-1089.

Keel, S.G., Leifeld, J., Mayer, J., Taghizadeh-Toosi, A., Olesen, J.E., 2017. Large uncertainty in soil carbon modelling related to method of calculation of plant carbon input in agricultural systems. Eur. J. Soil Sci. 68, 953-963.

Kell, D.B., 2011. Breeding crop plants with deep roots: their role in sustainable carbon, nutrient and water sequestration. Ann. Bot. 108, 407-418.

Kong, A.Y.Y., Six, J., Bryant, D.C., Denison, R.F., van Kessel, C., 2005. The relationship between carbon input, aggregation, and soil organic carbon stabilization in sustain able cropping systems. Soil Sci. Soc. Am. J. 69, 1078-1085.

Kupper, T., Bonjour, C., Menzi, H., Bretscher, D., Zaucker, F., 2018. Ammoniakemissionen der schweizerischen Landwirtschaft 1990-2015. Hochschule für Agrar-, Forst- und Lebensmittelwissenschaften, Bonjour Engineering GmbH, Oetiker + Partner AG.

Kuster, M., Herzog, F., Rehnus, M., Sorg, u.J.-P., 2012. Innovative Agroforstsysteme - on farm monitoring von Chancen und Grenzen. Agrarforschung Schweiz 3, 470-477.

Kuznetsova, A., Brockhoff, P.B., Christensen, R.H.B., 2017. lmerTest package: tests in linear mixed effects models. J. Stat. Softw. 82, 1-26.

Lal, R., 2011. Sequestering carbon in soils of agro-ecosystems. Food Policy 36, S33-S39.

Lee, J., Hopmans, J.W., Rolston, D.E., Baer, S.G., Six, J., 2009. Determining soil carbon stock changes: simple bulk density corrections fail. Agric. Ecosyst. Environ. 134, 251-256.

Lehmann, J., 2007. A handful of carbon. Nature 447, 143-144.

Leifeld, J., Bassin, S., Fuhrer, J., 2005. Carbon stocks in Swiss agricultural soils predicted by land-use, soil characteristics, and altitude. Agric. Ecosyst. Environ. 105, 255-266.

Leifeld, J., Reiser, R., Oberholzer, H.-R., 2009. Consequences of conventional versus organic farming on soil carbon: results from a 27-Year field experiment. Agron. J. 101, 1204-1218.

Liebisch, F., Buenemann, E.K., Huguenin-Elie, O., Jeangros, B., Frossard, E., Oberson, A., 2013. Plant phosphorus nutrition indicators evaluated in agricultural grasslands managed at different intensities. Eur. J. Agron. 44, 67-77.

Luo, Z.K., Wang, E.L., Sun, O.J., 2010. Can no-tillage stimulate carbon sequestration in agricultural soils? A meta-analysis of paired experiments. Agric. Ecosyst. Environ. 139, 224-231.

Mäder, P., Fließbach, A., Dubois, D., Gunst, L., Fried, P., Niggli, U., 2002. Soil fertility and biodiversity in organic farming. Science 296, 1694-1697.

Maltas, A., Kebli, H., Oberholzer, H.R., Weisskopf, P., Sinaj, S., 2018. The effects of organic and mineral fertilizers on carbon sequestration, soil properties, and crop yields from a long-term field experiment under a Swiss conventional farming system. Land Degrad. Dev. 29, 926-938.

Mandaliev, P., Schleiss, K., 2016. Kompostier- und Vergärungsanlagen. Erhebung in der Schweiz und in Liechtenstein. Bundesamt für Umwelt, Bern. Umwelt-Zustand
$1602,32$.

Martínez, I., Chervet, A., Weisskopf, P., Sturny, W.G., Etana, A., Stettler, M., Forkman, J., Keller, T., 2016. Two decades of no-till in the Oberacker long-term field experiment: part I. Crop yield, soil organic carbon and nutrient distribution in the soil profile. Soil Tillage Res. 163, 141-151.

Minasny, B., Malone, B.P., McBratney, A.B., Angers, D.A., Arrouays, D., Chambers, A., Chaplot, V., Chen, Z.-S., Cheng, K., Das, B.S., Field, D.J., Gimona, A., Hedley, C.B., Hong, S.Y., Mandal, B., Marchant, B.P., Martin, M., McConkey, B.G., Mulder, V.L., O'Rourke, S., Richer-de-Forges, A.C., Odeh, I., Padarian, J., Paustian, K., Pan, G., Poggio, L., Savin, I., Stolbovoy, V., Stockmann, U., Sulaeman, Y., Tsui, C.-C., Vagen, T.-G., van Wesemael, B., Winowiecki, L., 2017. Soil carbon 4 per mille. Geoderma 292, 59-86.

Minx, J.C., Lamb, W.F., Callaghan, M.W., Bornmann, L., Fuss, S., 2017. Fast growing research on negative emissions. Environ. Res. Lett. 12 35007-35007.

Oberholzer, H.R., Leifeld, J., Mayer, J., 2014. Changes in soil carbon and crop yield over 60 years in the Zurich Organic Fertilization Experiment, following land-use change from grassland to cropland. J. Plant Nutr. Soil Sci. 177, 696-704.

Pan, G., Smith, P., Pan, W., 2009. The role of soil organic matter in maintaining the productivity and yield stability of cereals in China. Agric. Ecosyst. Environ. 129, 344-348.

Persson, T., Bergkvist, G., Katterer, T., 2008. Long-term effects of crop rotations with and without perennial leys on soil carbon stocks and grain yields of winter wheat. Nutr. Cycl. Agroecosystems 81, 193-202.

Poeplau, C., Bolinder, M.A., Eriksson, J., Lundblad, M., Kätterer, T., 2015. Positive trends in organic carbon storage in Swedish agricultural soils due to unexpected socioeconomic drivers. Biogeosciences 12, 3241-3251.

Poeplau, C., Don, A., 2013. Sensitivity of soil organic carbon stocks and fractions to different land-use changes across Europe. Geoderma 192, 189-201.

Poeplau, C., Don, A., 2015. Carbon sequestration in agricultural soils via cultivation of cover crops - A meta-analysis. Agric. Ecosyst. Environ. 200, 33-41.

Poeplau, C., Don, A., Vesterdal, L., Leifeld, J., Van Wesemael, B.A.S., Schumacher, J., Gensior, A., 2011. Temporal dynamics of soil organic carbon after land-use change in the temperate zone - carbon response functions as a model approach. Glob. Chang. Biol. 17, 2415-2427.

Poulton, P., Johnston, J., Macdonald, A., White, R., Powlson, D., 2018. Major limitations to achieving "4 per 1000" increases in soil organic carbon stock in temperate regions: Evidence from long-term experiments at Rothamsted Research, United Kingdom. Glob. Chang. Biol. 24, 2563-2584.

Powlson, D.S., Stirling, C.M., Jat, M.L., Gerard, B.G., Palm, C.A., Sanchez, P.A., Cassman, K.G., 2014. Limited potential of no-till agriculture for climate change mitigation. Nat. Clim. Chang. 4, 678-683.

Richner, W., Sinaj, S., 2017. GRUD 2017, Grundlagen für die Düngung landwirtschaftlicher Kulturen in der Schweiz. Agrarforschung Schweiz 8, 1-276.

Schiedung, M., Tregurtha, C.S., Beare, M.H., Thomas, S.M., Don, A., 2019. Deep soil flipping increases carbon stocks of New Zealand grasslands. Glob. Chang. Biol.

Shah, G.M., Shah, G.A., Groot, J.C.J., Oenema, O., Raza, A.S., Lantinga, E.A., 2016. Effect of storage conditions on losses and crop utilization of nitrogen from solid cattle manure. J. Agric. Sci. 154, 58-71.

Sinaj, S., Jeangros, B., 2019. Préserver la durabilité des systèmes de grande culture: bilan de 50 ans d'essais à Changins. Recherche Agronomique Suisse 10.

Smith, P., 2016. Soil carbon sequestration and biochar as negative emission technologies. Glob. Chang. Biol. 22, 1315-1324.

Smith, P., Chapman, S.J., Scott, W.A., Black, H.I.J., Wattenbach, M., Milne, R., Campbell, C.D., Lilly, A., Ostle, N., Levy, P.E., Lumsdon, D.G., Millard, P., Towers, W., Zaehle, S., Smith, J.U., 2007. Climate change cannot be entirely responsible for soil carbon loss observed in England and Wales, 1978-2003. Glob. Chang. Biol. 13, 2605-2609.

Smith, P., Friedmann, J., 2017. Bridging the Gap - Carbon Dioxide Removal. The Emissions Gap Report 2017.

Smith, P., Martino, D., Cai, Z., Gwary, D., Janzen, H., Kumar, P., McCarl, B., Ogle, S., O’Mara, F., Rice, C., Scholes, B., Sirotenko, O., Howden, M., McAllister, T., Pan, G., Romanenkov, V., Schneider, U., Towprayoon, S., Wattenbach, M., Smith, J., 2008. Greenhouse gas mitigation in agriculture. Philos. Trans. Biol. Sci. 363, 789-813.

Sommer, S.G., Hutchings, N.J., 2001. Ammonia emission from field applied manure and its reduction-invited paper. Eur. J. Agron. 15, 1-15.

Stumpf, F., Keller, A., Schmidt, K., Mayr, A., Gubler, A., Schaepman, M., 2018. Spatiotemporal land use dynamics and soil organic carbon in Swiss agroecosystems. Agric. Ecosyst. Environ. 258, 129-142.

Thomet, P., Koch, B., 1993. Längerfristige Auswirkungen von Düngung und Schnittregime auf eine Heumatte. Landwirtschaft Schweiz 6, 107-114.

UNEP, 2017. The Emissions Gap Report 2017. UNEP, Nairobi.

Walther, U., Weisskopf, P., Oberholzer, H.-R., Knecht, K., 2001. 50 Jahre organische und mineralische Düngung: Humusgehalte, N-Ausnutzung und N-Bilanzen. Archiv für Acker- und Pflanzenbau und Bodenkunde 46, 265-280.

Wiesmeier, M., Hubner, R., Sporlein, P., Geuss, U., Hangen, E., Reischl, A., Schilling, B., von Lutzow, M., Kogel-Knabner, I., 2014. Carbon sequestration potential of soils in southeast Germany derived from stable soil organic carbon saturation. Glob. Chang. Biol. 20, 653-665.

Zeeman, M.J., Hiller, R., Gilgen, A.K., Michna, P., Plüss, P., Buchmann, N., Eugster, W., 2010. Management and climate impacts on net CO2 fluxes and carbon budgets of three grasslands along an elevational gradient in Switzerland. Agric. For. Meteorol. 150, 519-530.

Zihlmann, U., Jossi, W., Scherrer, C., Krebs, H., Oberholzer, H.R., Albisser Vögeli, G., Nemecek, T., Richner, W., Brack, E., Gunst, L., Hiltbrunner, J., van der Heijden, M., Weisskopf, P., Dubois, D., Oehl, F., 2010. Integrierter und biologischer Anbau im Vergleich. ART-Bericht, ART-Bericht 722, 16. 